Cadernos de Semiótica Aplicada

Vol. 4.n.2, dezembro de 2006

\title{
O SUINGUE FUNK DA CANÇÃO SLA
}

\section{SWING FUNK OF SLA SONG}

Luciane de Paula

UNESP/CAr. - Programa de Pós-graduação em Lingüística e Língua Portuguesa

\begin{abstract}
Resumo: Este artigo apresenta uma análise da canção funk de Fernanda Abreu (FA), vista como representante da canção funk carioca contemporânea, a partir de alguns conceitos da semiótica da canção, desenvolvida por Luiz Tatit. O objetivo do artigo é refletir acerca de alguns mecanismos desenvolvidos na canção "SLA radical dance disco club" de Fernanda Abreu para persuadir seu ouvinte a tomar gosto por esse gênero musical, a participar do "baile da pesada" do funk carioca e a fazer parte do "clube SLA" de FA. Para contextualizar o leitor, primeiro, retomamos o percurso histórico do funk no Rio de Janeiro e localizamos a presença da canção de Fernanda Abreu nesse quadro, depois, abordamos os conceitos semióticos utilizados na análise da canção e, por fim, analisamos a letra da canção "SLA radical dance disco club" como exemplo das SLAs de Fernanda Abreu e de seu funk carioca, parte (à parte) desse estilo musical.
\end{abstract}

Palavras-chave: suingue; funk carioca; Fernanda Abreu; SLA; semiótica da canção.

\begin{abstract}
This article presents an analysis of the song funk of Fernanda Abreu (FA), seen as of the song funk representative Carioca contemporary, from some concepts of the semiotics of the song, developed for Luiz Tatit. The objective of the article is to reflect concerning some mechanisms developed in song "SLA radical dance disco club" of Fernanda Abreu to persuade its listener to take taste for this musical style, to participate of the ball of funk Carioca and to be part of "SLA club" of FA. To context the reader, first, we retake the historical passage of funk in Rio de Janeiro and the presence of the song of Fernanda Abreu in this context, later, we approach the used semiotics concepts in the analysis of the song and, finally, we analyze the letter of song "SLA radical dance disco club" as example of the SLAs of Fernanda Abreu and its funk Carioca, part (to the part) of this musical style
\end{abstract}

Keywords: swing; funk carioca; Fernanda Abreu; SLA; semiotics of the song. 
CASA, Vol.4, n.2, dezembro de 2006

\section{Introdução}

Este artigo é resultado de parte de nossa tese de doutorado e propõe analisar a letra da canção "SLA radical dance disco club", como exemplo das canções SLAs" de Fernanda Abreu (FA) e representante da proposta de suingue da canção funk carioca contemporânea. Para isso, aplicamos alguns conceitos da semiótica da canção desenvolvida por Tatit, bem como nos calcamos em conceitos clássicos da semiótica greimasiana, a fim de compreender e refletir acerca de alguns mecanismos desenvolvidos pelos destinadores-locutores ${ }^{2}$ das canções SLA para persuadir seus destinatários-ouvintes, por meio de interlocutores, a apreciar esse gênero musical, a participar do "baile da pesada" do funk carioca e a fazer parte do "clube SLA”.

\footnotetext{
${ }^{1}$ Uma discussão acerca do sentido da sigla SLA será apresentada no item "O suingue SLA 'radical dance disco club' de FA" deste trabalho.

2 As designações "destinador-locutor" e "destinatário-ouvinte" são utilizadas por nós porque, segundo Tatit (1986, p. 6), a definição de "locutor” advém “(...) tanto da origem etimológica (loquor = 'falar', 'exprimir', 'dizer') como do senso-comum”, pois “(...) define alguém que se expressa com as articulações vocais. A fala e sua extensão estética, o canto, pressupõem necessariamente um sujeito locutor. Este termo define melhor a posição sintáxica de 'alguém que canta', antes que seja preenchida pelo compositor, pelo cantor, pelo intérprete, ou qualquer outra personificação. O locutor é apenas uma posição gramatical da canção”. Assim, para a síncrese apresentada na própria conceituação de locutor, Tatit formula o termo composto Destinador-Locutor. Segundo Farias (1997, p. 137), "Na relação destinador-locutor e destinatário-ouvinte, o primeiro é o sujeito que conta uma história qualquer de uma maneira diferenciada, ao cantar o enunciado. Esse gesto causa a impressão de que a canção é construída no momento em que é cantada", isso porque, segundo Tatit (1996, p. 20), "o núcleo entoativo da voz engata a canção na enunciação produzindo efeito de tempo presente: alguém cantando é sempre alguém dizendo, e dizer é sempre aqui e agora". O cantor, então, parece incorporar os diferentes fazeres que encontramos quando nos deparamos com um texto. Nesse sentido, a tarefa do destinador-locutor é fazer com que o destinatário-ouvinte reconheça, na canção, situações cotidianas, ao instaurar um interlocutor e um interlocutário que simulam a sua relação com o destinatário-ouvinte. Dessa maneira, conforme salienta Tatit (1986, p. 10): "quando o locutor se materializa num timbre de voz qualquer (o cantor), o ouvinte não consegue dissociar com nitidez a comunicação principal (destinador-locutor/destinatário-ouvinte) de seu simulacro (interlocutor/interlocutário), pois o sujeito parece ser o mesmo. De fato, a figura do cantor sincretiza as duas posições, destinador-locutor e interlocutor, e isso causa no ouvinte a impressão de que a cena relatada pela canção é viva. Durante o mesmo tempo que o interlocutor fala com o interlocutário, o destinador-locutor canta para o destinatário-ouvinte. A locução é uma só. Pelo texto, temos a construção do simulacro, pela melodia, a sua presentificação. Um timbre de voz produzindo a melodia revela a entonação simultânea do interlocutor e do destinador-locutor (sincretizados), fazendo com que a locução principal e o simulacro de locução tenham o mesmo tempo de existência: o tempo da canção". O simulacro construído atribui à canção uma proximidade das situações presenciadas pelo destinatário-ouvinte, o que causa um efeito de sentido de reconhecimento. Esse é o primeiro passo para que se estabeleça o contrato de crença entre destinador-locutor e destinatário-ouvinte, que constitui o que Tatit denomina "persuasão figurativa". Assim, podemos dizer que o destinador estabelece a seguinte relação com o destinatário: o destinador-locutor desenviolve um Programa Narrativo (PN) de persuasão ao propor um contrato fiduciário ao destinatário-ouvinte. Caso esse contrato se confirme, o passo seguinte do destinador-locutor é o fazer manipulatório. Em outras palavras, a relação entre os dois actantes da comunicação, destinador-locutor e destinatário-ouvinte, pode ser descrita como uma ação do primeiro sobre o segundo, inicialmente uma persuasão /fazer-crer/ e, posteriormente, uma manipulação /fazer-fazer/. A persuasão é garantida pelas modalidades /saber-fazer/ e /poder-fazer/, que qualificam e, ao mesmo tempo, realizam o destinador-locutor como sujeito do /fazer/. Isso porque ele sabe sobre a competência do destinatário-ouvinte ou constrói um simulacro, a fim de poder influenciá-lo e persuadi-lo, pois oferece o tipo de canção desejado pelo destinatário-ouvinte. Tudo isso resulta na adesão do destinatário-ouvinte ao contrato proposto pelo destinadorlocutor.
} 
As letras das canções SLAs retratam a questão da própria definição de funk e da festividade musical como alicerce das relações entre os sujeitos de seus enunciados, pois a estrutura dessas canções se centra nos sujeitos. Melhor, na manipulação por sedução entre os sujeitos. Por isso, também embasamo-nos em Barros (1990) e Bertrand (2003), ainda que esses dois últimos não tratem de canções.

Em nossas pesquisas acerca das canções funk de FA, percebemos o quanto a isotopia ${ }^{3}$ da busca por um pertencimento, feita por um certo grupo, prevalece no discurso verbal tanto das canções de FA quanto do funk carioca. A preocupação existente em muitas das canções funk se refere à procura de um espaço, hoje (mas também historicamente), no Rio de Janeiro (mas não só, embora o Rio seja representante do locus estabelecido pela mídia, principalmente, televisiva, como lugar pelo qual se tem que passar e ser visto), pelos sujeitos das canções. As canções de Fernanda Abreu, nesse sentido, expressam o processo de "funkinização" pelo qual passa o país.

Compreendemos a "funkinização" no Brasil como um processo de produção contemporâneo de uma nova tendência cultural, desenvolvido no Rio, a partir dos anos 70, ainda em formação e transformado em "moda", ao longo dos anos 90, e hoje espalhado por todo o país, ainda que o vínculo com a cidade do Rio de Janeiro seja mais acentuado, pois é lá que o funk é produzido e de lá é que se espalha por todo o território nacional. O processo por que passa, o funk carioca, como produto cultural, é incorporado pela indústria cultural, que começa a ver nessa arte um filão de consumo a ser explorado. Com esse intuito, os meios de comunicação de massa passam a "valorizar" o baile funk e toda a produção de consumo dele oriunda, ou seja, a linguagem ("gíria", que, no processo de "funkinização", passa a ser um código, quase outro idioma, porta de entrada para um outro universo, bem como para a compreensão de uma lógica cultural diferente da já estabelecida), a roupagem (que passa a ser encarada como moda e, portanto, valorizada como tal, originando griffies), a música, a dança e a arte do e no corpo (tatuagens e piercings), a fim de disseminar uma outra lógica, a da festa, com o propósito de conquistar adeptos a essa arte e, com isso, atrair novas possibilidades de produção/geração, circulação e reprodução de renda.

Com vistas nesse processo é que elegemos a canção "SLA radical dance disco club" de FA como corpus deste artigo, a ser analisada sob o prisma da festa, componente da isotopia do pertencimento, marca explorada na maioria das letras das canções de FA e do funk

\footnotetext{
${ }^{3}$ De acordo com Barros (1990, p. 87), a isotopia pode ser entendida como "reiteração de quaisquer unidades semânticas (repetição de temas ou recorrência de figuras) no discurso, o que assegura sua linha sintagmática e sua coerência semântica". Para reiterar e complementar Barros, buscamos a mesma definição em Bertrand (2003, p. 420-1), que compreende isotopia por "Recorrência de um elemento semântico no desenvolvimento sintagmático de um enunciado, que produz um efeito de continuidade e permanência de um efeito de sentido ao longo da cadeia do discurso. (...) a isotopia não tem por horizonte a palavra, mas o discurso. Ela pode assim referir-se ao estabelecimento de um universo figurativo (isotopias de atores, tempo e espaço), mas também à tematização desse universo (isotopias abstratas, temáticas, axiológicas), e, sobretudo, à hierarquia entre as isotopias de leitura (por identificação de um núcleo isotopante que rege as isotopias de nível inferior). Conectando as isotopias, as figuras de retórica (metáfora, metonímia, etc.) instalam a coexistência extensiva e eventualmente competitiva de dois ou mais planos de significação simultaneamente oferecidos à interpretação.". A isotopia da busca por um pertencimento é um dos possíveis núcleos isotopantes das canções de FA. Como o conceito de isotopia se relaciona ao conceito de sentido, uma vez que se refere, como afirma Dubois (1978), calcado em Greimas, a uma "propriedade semântica", ele pode ser composto, como no caso das SLAs, por mais de uma isotopia. Em FA, de acordo com nossa leitura, o núcleo isotopante da busca por um pertencimento se encontra vinculado a três isotopias temáticas de leitura: a festa, a antropofagia e a metalinguagem. Esses três traços semânticos não são os únicos, mas representam boa parte de suas canções. Por isso, não podem ser analisados separadamente, o que justifica que, ainda que enfatizemos, aqui, a festa, esse traço se intercambia com os demais, que se apresentam simultaneamente.
} 
carioca. O baile cantado por FA aparece em suas SLAs como rito de passagem, pois é o "suingue" SLA que aparece como elemento caracterizador de alguns sujeitos do funk cantados pelos destinadores-locutores de suas canções.

Para entendermos a estrutura enunciativa tanto das SLAs de FA quanto da canção funk, estruturamos este artigo em três momentos: primeiro, a historicização do funk; segundo, a conceituação de alguns elementos semióticos utilizados em nossa análise, bem como a conceituação semiótica da canção funk; e, por fim, a análise de "SLA radical dance disco club" como exemplificação das SLAs de FA e do processo de "funkinização" pelo qual passa o país na contemporaneidade.

Assim, após compreender as canções SLAs de FA, a partir da análise semiótica de "SLA radical dance disco club", pudemos entendê-las como caso à parte do processo de "funkinização" carioca, uma vez que elas, como vemos na retomada histórica que se segue, no item "O funk SLA de Fernanda Abreu: sampler black power carioca", não se caracterizam exatamente como funk, tal qual o descrevemos; ao contrário, possuem, ao mesmo tempo, elementos específicos das três fases do funk carioca em suas composições, tanto musicais quanto em suas letras. Isso inclui e exclui as SLAs de FA do processo de "funkinização" carioca, pois, ao mesmo tempo, é resistente e entorpecente, uma tentativa de sobrevivência capital por meio do suingue.

\section{O funk SLA de Fernanda Abreu: sampler black power carioca}

O nome funk aparece nos Estados Unidos e denomina um tipo muito específico de música, que descende dos lamentos negros e rurais do blues, do posterior rhythm'n'blues, conhecido também como $R \& B$ (quando o blues chega aos grandes centros e ganha marcação rítmica mais vigorosa) e da evolução do rhythm'n'blues, o soul (quando o estilo ganha apuro melódico, emprestado da música das igrejas batistas, e esmero instrumental). Do soul, chegamos ao funk, redução à percussão básica do soul. O foco das músicas se desloca para a bateria (que passa a fazer desenhos rítmicos cada vez mais sincopados, próximos da raiz africana) e para o baixo elétrico (que responde pelo arcabouço melódico). Juntos, eles fazem o groove (o balanço), que é a essência do suingue, complementado por guitarras, metais e vocais agressivos. A partir de meados da década de 60, esse som fica conhecido como funk. Desse momento em diante, essas quatro letras passam a representar a senha para a dança frenética, suada e compromissada apenas com a diversão e com o prazer (inclusive sexual). O grande nome do funk norte-americano é James Brown. Autor de hinos à sexualidade aflorada (Sex Machine), à alegria irrestrita [I Feel Good (I Got You)] e à busca por direitos iguais para os negros [Say it Loud (I'm Black and I'm Proud)].

No entanto, não podemos nos esquecer, segundo Frenette (2006), que o funk é influenciado musicalmente pelo minimalismo ${ }^{4}$, por isso permite afirmações como a de Fausto Fawcett, que insere o ritmo na vertente experimental e afirma ter o funk carioca um valor melódico superior que faz "qualquer outro instrumento parecer desnecessário": o ritmo forte e vigoroso que tanto seduz, seja para aproximação seja para o distanciamento dessa música, ou seja, o vigor visceral de música primal minimalista. Assim, funk é, segundo Frenette, um termo que denomina as "variações anárquicas e polirrítmicas da música soul e define um estilo musical com forte marcação rítmica (groove) de baixo e bateria. Podemos dizer ainda

\footnotetext{
${ }^{4}$ Minamalismo, escola musical composicional com harmonias estáticas e repetições padronizadas que reduzem radicalmente os elementos compositivos.
} 
que o funk carioca é uma espécie de primo debochado e desaforado do rap, uma vez que esses gêneros são minimalistas e baseiam-se em batidas eletrônicas pré-gravadas ou sampleadas".

De acordo com a conceituação da Wikipédia (2006), os músicos negros norteamericanos dos anos 30 chamavam de funk a música com um ritmo mais suave, já que ele possuía forte influência das igrejas batistas negras e, em sua origem, versava sobre temas mais amenos. Posteriormente, ao longo dos anos 40, no entanto, os músicos passaram a denominar funk as canções com um ritmo mais intenso e agitado, por causa da associação da palavra funk com a dança e com o ato sexual, uma vez que a designação funk passou a se relacionar ao odor do corpo durante a dança e às relações sexuais - fuck. Essa última forma, também inicial, de música estabeleceu o padrão para músicos posteriores: uma música com um ritmo mais sexy, solto, orientado para frases musicais repetidas (riffs) e, principalmente, dançante. Funk (ou funky, encontramos os dois registros) era um adjetivo típico da língua inglesa para descrever essas características. A essência da expressão musical negra norte-americana tem suas raízes nos spirituals, nas canções de trabalho, nos gritos de louvor, no gospel e no blues. Na música contemporânea, o gospel, o blues e suas variantes tendem a se fundir e o funk se torna, assim, um amálgama do soul, do jazz e do rhythm'n'blues.

Todavia, apenas com as inovações de James Brown e Sly ${ }^{5}$ and the Family Stone, no final dos anos 60, é que o funk passou a ser considerado um gênero musical autêntico. Essas bandas de canto dançante e coreografias bem ensaiadas criaram um estilo repleto de vocais e coros de acompanhamento cativante. Brown mudou a ênfase rítmica 2:4 (dois por quatro) do soul tradicional para uma ênfase 1:3 (um por três), anteriormente associada com a música dos brancos - porém com uma forte presença da seção de metais. Com isso, a batida 1:3 se tornou marca registrada do funk.

O funk ganhou espaço na mídia brasileira há pouco menos de uma década, embora sua história tenha quase trinta anos. Sua principal característica é o suingue. No Brasil, a soul music, a atitude e o estilo norte-americano do black power fundaram o movimento Black Rio. Alguns artistas brasileiros, como Don Salvador e Grupo Abolição, Tim Maia, Carlos Dafé, Sandra de Sá, Tony Tornado, Gerson King Combo, Hyldon, Lady Zu, Cassiano e Banda Black Rio logo assimilaram essa tendência.

Podemos dizer que o funk carioca passa por seu terceiro ciclo. O primeiro ciclo ocorre com o aparecimento do funk no Brasil, entre as décadas de 60 e 80, denominado como "fase black power" ou soul-funk. Os bailes dessa época acontecem nas comunidades (silogismo de favelas) e, alguns, no Canecão. Um dos maiores sucessos é "Mandamentos Black", de Gerson King Combo. O segundo ciclo ocorre ao longo da década de 90 e se caracteriza pela crítica social, pela denúncia e pela violência. A realização dos bailes ocorre, nesse momento, em comunidades, clubes e boates. O terceiro ciclo, denominado "new funk", instaura-se no início dos anos 2000. A violência diminui e o espaço fica aberto à liberação do sexo, da pornografia e da promiscuidade. Os maiores sucessos desse momento são "Vou Passar Cerol Na Mão", "Adestrador" e diversas canções que apelam para a sexualidade. Os bailes se espalham pelo Brasil, dominando redutos de outros ritmos, como as quadras de escolas de samba, no Rio de Janeiro e o pelourinho, em Salvador (BA), por exemplo.

Quando surge, nos anos 70, Gerson King Combo é porta-voz do movimento Black Rio, ao redigir os dez mandamentos ${ }^{6}$ da cultura negra - os "Mandamentos Black"

\footnotetext{
${ }^{5}$ Sly nos remete, foneticamente, às SLAs de FA, bem como a referência presente em suas canções tanto à "black power" quanto à "disco club music", ambas as expressões próprias dos anos 60 e 70.

${ }^{6}$ Os dez mandamentos black são: "1. Dançar como dança um black; 2. Amar como ama um black; 3. Andar como anda um black; 4. Pulsar sempre cumprimento black; 5. Falar como fala um black; 6. Viver sempre na
} 
(transformados em canção de título homônimo). FA, além de também se relacionar e cantar músicas do funk carioca atual, em suas canções, faz menção constante ao soul, a King Combo e a seus "mandamentos black" (como ocorre na canção "Bloco Rap Rio 2006", em que o sujeito da canção, cita alguns dos mandamentos escritos por Combo como uma espécie de "pregação" de irmandade).

A música tocada nos bailes da década de 80 era conhecida como funk, contudo, identificava-se, principalmente, com o Miami Bass e o Freestyle. O Miami Bass era repleto de letras com palavrões e insuações eróticas. O funk carioca, já naquela época, era conhecido também como "balanço" (hoje, denominado como "bundalelê"), provavelmente devido ao modo de dançar/balançar o corpo.

Em 1990/2000, as letras tentam retratar a "realidade" e a pobreza do Rio. Drogas, violência e criminalidade são temas explorados, embora também existam canções que tratem de outros assuntos. Surge a competição entre as "galeras". Inicialmente, competia-se para ver qual comunidade tinha a melhor coreografia. Com o tempo, em alguns bailes, a competição se torna violenta e é implantado, como parte do baile, o "corredor da morte": a pista é dividida em dois "lados" (chamados de "Lado A' e "Lado B", por alusão às faces do disco de vinil) e um integrante de uma "galera" é escolhido pela "turma" inimiga para ser agredido. As meninas são levadas ao banheiro e, lá, agredidas e violentadas. Em meados de 2000, as letras se tornaram mais sexualizadas. Essa nova "fase" determina a origem do new funk, calcado na "liberação geral" sexual.

A primeira SLA, "SLA radical dance disco club", institui o "clube SLA" de FA como som do "baile da pesada", calcado na "liberação total" à qual nos referimos acima. Nesse sentido, a definição e a estruturação do baile surgem como condição sine qua non para a compreensão das canções SLA de FA e sua relação com o processo de "funkinização" brasileiro, uma vez que ela possui características tanto do soul funk da década de 70 quanto do new funk dos anos 90 e 2000.

Podemos caracterizar os bailes funk, denominados também como "bailes da pesada" na década de 70, em que o funk era a música black, com seus valores e mandamentos/pregações, influenciado pela soul music, em três tipos, de acordo com o local de suas realizações: (1) os bailes da zona sul; (2) os bailes destinados às classes mais abastadas economicamente, que também se realizam em boates; por fim, (3) os bailes funk também acontecem nas favelas cariocas e se dividem em "Bailes de Clube", e "Bailes de Comunidade". O baile funk também pode ocorrer "no meio da rua" de uma comunidade/favela. A infraestrutura, assim como a segurança, depende do local e da comunidade onde acontece a festa.

A "dance disco club", tema da "SLA radical dance disco club" de FA, caracteriza-se como uma dança sensual, coreografada, em grupo, embalada por uma música dançante, o soul-funk com sua batida techno e suingada (um por três), calcada num discurso verbal de irmandande, igualdade, "paz e amor", mas também sexo, amor, amizade, crítica social e questões cotidianas.

As canções de FA se relacionam com os funkeiros atuais e, ao mesmo tempo, voltamse ao som de discoteca ("disco club") e do soul-funk ("baile da pesada"), bem como aos valores pregados pelo movimento black de irmandade "paz e amor". Aliás, a "apologia" à dance music e à festividade, tão presente nas SLAs de FA, é o primeiro "mandamento black". Esse é um fator importante para o estudo das canções de Fernanda, pois, nelas, encontramos,

onda black; 7. Ter orgulho de ser black; 8. Curtir o amor que ouve um black; 9. Suingar como suinga um black; 10. Saber que a cor branca é a cor da bandeira da paz e da pureza, e que esses são os pontos de partida para toda coisa boa, devido a razão pela qual eu amo você também, brother". 
sincopados, os três tipos de funk aos quais nos referimos, especialmente a primeira "fase", recuperada, num outro contexto, com um outro sentido, o que atribui uma dimensão histórica ao funk de suas SLAs.

\section{O modo suingue das canções "SLA funky club" de FA}

O objeto de estudo da semiótica não se limita às instâncias da frase, uma vez que compreende que no interior de qualquer enunciado existem elementos que se articulam e compõem o sentido do texto. A semiótica observa que a produção do sentido possui um percurso definido como uma seqüência de níveis. Cada um desses níveis pode ser descrito, a fim de demonstrar a produção e possibilitar a interpretação do sentido. O processo gerador de sentido inicia-se nos elementos mais simples e abstratos, do nível profundo até aqueles mais complexos, na superfície do enunciado. Assim, o modelo semiótico possibilita explicitar a estrutura das canções de FA, a partir da "gramática" que rege a construção do sentido de seus textos.

A canção nasce do processo de composição e de musicalização, sendo que o último pode ser anterior, posterior ou concomitante ao texto. Segundo Tatit (1996, p. 49), o "ato de cantar finaliza esse processo e inicia outro, que envolve a relação entre sujeitos". Afinal, segundo Tatit (1996, p. 9), cantar constitui "uma gestualidade oral, ao mesmo tempo contínua, articulada, tensa e natural, que exige um permanente equilíbrio entre os elementos melódicos, lingüísticos, os parâmetros musicais e a entonação coloquial”. Esse gesto utiliza as pregas vocais como o "instrumento" que temos ao nosso alcance. Além disso, o indivíduo canta quando sente a necessidade de materializar o estado passional em que se encontra.

Podemos refletir também a respeito do papel da entonação que, na canção, pode ser bastante acentuada. Sua modulação cumpre o papel de embalar ou acompanhar o texto. Enquanto o texto obedece a uma estrutura sólida que o torna coeso e coerente, pois, de acordo com Tatit (1986, p. 7), "as entonações não têm outra função a não ser aquela de enfatizar, aqui e ali, as informações mais pertinentes do texto".

Ao compositor cabe realizar a tarefa de elaborar a acomodação das entonações às acentuações das palavras do texto, pois, conforme Tatit (1996: 212), "uma palavra que fira o projeto rítmico ou a regularidade dos acentos distribuídos ao longo das inflexões é normalmente substituída ou transferida para um outro lugar onde não quebre a simetria". Ao desempenhar essa tarefa, segundo Farias (1997, p. 128),

ele inicia o processo que faz o ouvinte ter a impressão de dialogar com o intérprete e com a canção. Esse efeito se reforça porque temos por hábito, na memória, a noção de que, quando alguém se dispõe a enunciar, há sempre uma resposta, o que implica estabelecer um diálogo.

De modo geral, segundo Tatit (1986), as canções apresentam apenas o papel do interlocutor em síncrese com o destinador-locutor. O interlocutário é um actante pressuposto no espaço discursivo da canção. Seu lugar é preenchido pelo destinatário-ouvinte, que se identifica nessa posição devido ao simulacro estabelecido. A atitude de identificação do destinatário-ouvinte com os atores da canção é facilitada pela presença dos dêiticos. Assim, os dêiticos desempenham um papel relevante de construção da verdade da situação enunciativa. A sua utilização na canção é uma situação de "presentificação locutiva", pois eles são elementos lingüísticos que servem para caracterizar uma relação entre dois sujeitos. Além disso, marcam a opção pelo enfoque utilizado na canção, a fim de causar determinados 
"efeitos de sentido". De acordo com Tatit (1986, p 66), "O uso dos dêiticos constrói na canção uma situação locutiva". Por meio da dêixis discursiva eu-aqui-agora (a debreagem enunciativa, em termos semióticos), por exemplo, a cena descrita parece ocorrer no momento em que é executada a canção. A dêixis discursiva é organizada, como afirma Farias (1997, p. 142) "de modo a obter o efeito de verdade e realidade ao lado do uso de vocativos, imperativos, exclamações e gírias. As modulações melódicas que acompanham esses vocábulos contribuem para a obtenção de tal efeito, pois seguem o desenho atribuído pelo fio discursivo do texto".

O uso do vocativo tem por função marcar a presença do sujeito, pois o ato de chamar é característica de quem deseja iniciar um diálogo, o que causa, segundo Tatit (1986, p. 18), "a impressão de que a cena se passa no próprio transcorrer da canção", enquanto a música marca a sua presença com alteração do seu percurso sonoro. Além disso, com o vocativo, o "eu" (destinador-locutor) chama a atenção do "outro" (destinatário-ouvinte) ao convidá-lo a ouvir a canção. O imperativo reforça a presentificação da situação de enunciação, principalmente quando o "outro" é nomeado, pois o imperativo é um apelo. Assim, quando o imperativo aparece, a melodia, conforme Tatit (1996, p. 18-9), concomitantemente, apresenta uma ascendência na entonação típica da interrogação, o que causa a expectativa de que, a seguir, haverá uma resposta. Esse recurso provoca, no destinatário-ouvinte, um estado de atenção.

As gírias (como "galera", "irmão", "sangue bom" e "sampleia", dentre outras que aparecem nas canções de FA e fazem parte do universo jovem e/ou do funk) e as "frases feitas" ("o céu pode esperar", "a solução pros seus problemas acabou de chegar", dentre outros ditos populares e demais chavões) são soluções encontradas pelo destinador-locutor para marcar o discurso direto na canção. Esses recursos indicam a presença da linguagem coloquial e reforçam o "efeito de presentificação" da cena do diálogo, pois se trata de uma situação comum.

No texto da canção popular, a deitização e o uso da linguagem coloquial são processos paralelos ao da entoativização, que tem a finalidade de completar a figurativização, a qual permite ao destinatário-ouvinte percebê-la como situação locutiva possível de acontecer e o efeito é o de presentificação.

Os dêiticos espaciais, por sua vez, visam estabelecer uma demarcação na canção. Por meio deles são definidas as posições do interlocutor e do interlocutário em relação à canção, bem como a configuração do ambiente físico descrito. O deslocamento espacial do interlocutor, como ocorre, por exemplo, em "S.L.A. radical dance disco club", como veremos na análise que se segue, é percebido pelo destinatário-ouvinte na medida em que o destinadorlocutor "mostra" os lugares, respectivamente casa e pista de dança (subentende clube ou boate), que representam os estados inicial e final do sujeito do enunciado. Nesse caso, o uso dos pronomes demonstrativos, artigos definidos e indefinidos, advérbios de lugar ou nomes de objetos ganham papel importante na referencialização. $\mathrm{O}$ espaço construído é aquele descrito no decorrer da canção.

Algumas canções de FA têm como tema predominante a descrição de lugares e situações que criam "quadros" onde o destinatário-ouvinte se projeta ou tem a ilusão de visualizá-los. Por vezes, essa ilusão é tão expressiva que os ouvintes podem chegar a se lembrar de determinada canção como uma cena de um filme. Paralelo à descrição do ambiente, o uso dos pronomes demonstrativos também caracteriza a gestualidade da canção. Segundo Tatit (1986, p 21-2), no momento em que são utilizados, há uma sugestão visual que solicita a memória do destinatário-ouvinte e o faz "ver" as situações ocorridas na canção. O interlocutor acompanha cada verso com "gestos" que complementa "visualmente" a 
informação dada, como o de andar, pensar, sentir, trabalhar, dançar, como ocorre em "SLA radical dance disco club".

Os tempos verbais, nas canções de FA, marcam as ações dos sujeitos e reforçam os efeitos já desencadeados. Segundo Tatit (1986, p. 77), "O tempo presente, além de criar a presentificação, fortalece a síncrise existente entre as relações dos sujeitos. De modo geral, o uso dos pretéritos, somado aos efeitos do presente, aparece como memória ou configura a evolução de sua história. Já o tempo futuro tem o objetivo de retratar o sentimento de esperança ou ser uma premonição do que pode acontecer". As estratégias desenvolvidas nas canções de FA são utilizadas com o objetivo de criar o efeito de sentido de tornar o momento da execução da canção um fato presente. A alternância entre tensão e distensão serve para manter a atenção no enunciado e traduzir o seu equilíbrio. No caso de FA, um des-equilíbrio entorpecente em busca de um equilíbrio resistente, na tentativa de afirmar seu clube SLA como suingue festivo rebelde.

\section{O suingue SLA "radical dance disco club" de FA}

O título da canção "SLA radical dance disco club" já propõe um significado festivo para SLA. Todavia, antes de analisarmos isso, é importante dizer que a sigla de FA, em diversas canções utiliza o paragrama como recurso lingüístico que aproxima as SLAs a "Lucy in the Sky with Diamond". Tringali (1988, p. 127) conceitua esse processo lingüístico da seguinte forma: "PARAGRAMA - para Saussure consiste em espalhar num texto as letras de uma palavra ou frase. Veja-se este verso de Baudelaire: Sur mon crâne incliné PLantE son drapEau Noir, onde se lê 'spleen"”. A forma recorrente desse tipo de composição (as iniciais maiúsculas SLA) ratifica a relação proposta por nós entre a sigla de Abreu e a canção "Lucy in the Sky with Diamond", dos Beatles, pois o recurso retórico de composição é o mesmo: as iniciais maiúsculas formam uma sigla, todavia o enunciado formado por essas iniciais compõe uma metáfora que vela sua tentativa resistente e entorpecente de instaurar, na Terra, um mundo ideal, calcado na alucinação do baile funk, embalado pelo som SLA (o LSD de FA) como rebeldia deslocada. Estruturada de maneira paragramática, SLA passa a ser um sigla. Essa sigla é entendida por nós como um código, um "idioma" que, de certa forma, é responsável pela instauração do universo da festa, com a caracterização do prazer como forma de poder, colocado como tema central nas canções de FA, como ocorre em "SLA radical dance disco club". Por isso, não podemos esquecer as possíveis significações da sigla SLA para compreendermos sua imbricação com o poder e o motivo de nossa leitura do baile, calcada no tripé sujeito-espaço-tempo.

Relacionamos a sigla SLA com a canção "Lucy in the Sky with Diamond" pelo processo paragramático e também pela apologia ao $L S D$, pois, conforme demonstra nossa análise, o estado de entorpecência/resistência é uma característica componente das canções de FA, ou seja, um estado de "desligamento" e "ligação", como propõe Timothy Leary (com

\footnotetext{
7 As expressões "se liga" e "tá ligado" foram criadas por Timothy Leary, o "doutor da percepção", assim conhecido por seus estudos sobre o LSD. Leary dizia que o $L S D$ era um elemento de "expansão da consciência" que "desligava" seu usuário da "realidade" do mundo mental e o "ligava" ao universo dos sentidos, por meio da sensibilidade aflorada. Segundo Aldous Huxley (2002), os dois sentidos mais afetados pelo LSD e, portanto, responsáveis por "ligar" o sujeito e abrir "as portas" de sua "percepção", são a audição e a visão, misturadas, muitas vezes, com suas capacidades perceptivas descritas de maneira invertida, tamanho o aumento da potencialidade desses dois sentidos pelo acido lisérgico, tanto que uma das descrições de alucinação mais famosas de Hoffman (o farmacêutico que conseguiu sintetizar o cristal em laboratório), causada pelo $L S D$, é a de que "você pode ver o som e ouvir a luz de um outro mundo".
} 
relação ao $L S D$ ), a uma outra dimensão. Melhor, uma tentativa, ao mesmo tempo, de resistência contracultural e dispositivo fugidio, momentâneo, que colabora para a garantia e a manutenção do sistema. Assim, a ênfase ao "baile da pesada" como locus próprio de "alucinação", que tira o sujeito de seu cotidiano e modifica seu estado de ânimo, é uma das maiores características das canções de FA, como ocorre em "SLAs radical dance disco club". Assim, o baile aparece nas canções como figura que, ao mesmo tempo, caracteriza a tentativa de resistência e a fuga entorpecente da "realidade" em que os sujeitos se encontram. A resistência ocorre pela instituição do prazer, do lazer e da festa no lugar da obrigação, enquanto a entorpecência aparece, principalmente, por meio do ritmo "batidão" do funk eletrônico das canções, que reproduzem o mecanismo autorizado de ilusão de poder e fuga do "real".

As siglas e a língua inglesa fazem parte do universo do funk carioca e compõem parte expressiva da obra de FA. A sigla criada por ela, SLA, é uma marca constante em toda a sua produção e se refere à identidade da cantora-compositora, já que é composta pelas iniciais de seu nome: (Fernanda) Sampaio de Lacerda Abreu. Todavia, em suas canções, a sigla se desprende de Fernanda e adquire dimensões mais amplas. SLA se refere ao aspecto da metalinguagem, componente da isotopia da busca por um pertencimento. Não um pertencimento pessoal da cantora, mas a representação de uma busca coletiva, representada pelos sujeitos de suas canções, por seu /querer/ ocupar um espaço: o "dance disco club" carioca, miscigenado pelas misturas musicais que compõem a unidade heterogênea das SLAs.

As canções de FA ou possuem títulos homônimos aos álbuns nos quais se encontram ou se caracterizam como uma espécie de metalinguagem a respeito das possibilidades de simbolizações e decifrações da sigla SLA, que representa um tempo suspenso, o momento presente, num locus utópio, o clube do "baile da pesada", a faceta dançante do Rio de Janeiro, voltada para os sujeitos que queiram se "desligar" do mundo "real" e se "ligar" ao universo SLA.

Ao analisarmos as SLAs, percebemos que tal sigla não possui um único significado. Ao contrário, ela representa a possibilidade de realização de diversas idéias por meio de palavras que podem ser criadas a partir de suas iniciais. Nesse sentido, ela adquire autonomia. Afinal, por um lado, se a canção "SLA 2" propõe o significado "Sigla Latina do Amor" à sigla, por outro, "S.L.A. 3" utiliza suas iniciais para os mais diversos vocábulos, todos referentes a São Sebastião do Rio de Janeiro e "SLA radical dance disco club" sugere ainda para a sigla o significado de um som radical, resistente e entorpecente, típico das pistas de dança. Apesar da significações distintas, as duas primeiras SLAs utilizam o paragrama como recurso composicional, enquanto a terceira sugere a significação da sigla ao colocá-la como adjetivação do "baile da pesada" e especificação do "clube radical". Melhor, um tipo de som/música - quente e de "liberação". Essa é a maneira como a sigla aparece pela primeira vez: código próprio de uma "balada" própria, com objetivo, comunidade, tempo e sujeitos específicos.

$\mathrm{Na}$ análise que se segue, vemos que, em "SLA radical dance disco club", o tema central é a instituição do universo SLA no mundo "dance" (como intermédio entre o "clube funk" das décadas de 70 e 90/2000 com a propriedade de deslocamento de FA - dentro e fora do movimento) no lugar do universo do trabalho-obrigação. O mundo "dance" ao qual as SLAs se vinculam é o suingue da música black. A música SLA, dançante, aparece, nas canções, como momento de "vadiagem" saudável, prazerosa e resistente, pois elemento transformador e "aliviador" da "condição" de obrigação dos sujeitos que, habitantes disfóricos do universo do trabalho, compostos pelo cotidiano monótono, estático, mental, rotineiro, sério e racional, podem "solucionar" "seus problemas" por meio da dança, possível apenas com a 
música SLA e, assim, deixar de pertencer a um mundo que não os identifica como sujeitos "visíveis" e passar a poder pertencer ao "clube" do "baile da pesada", universo calcado nas regras do corpo, do prazer, do lazer, do riso, da diversão, do inusitado, da movimentação, dos sentidos e que "oferece" (ou impõe) uma outra lógica e um novo sentido à existências dos sujeitos.

A transformação de estados, monótomo e disfórico para surpreendente, sedutor e eufórico, narrada em "SLA radical dance disco club" (reproduzida em anexo) e sofrida pela "menina", "personagem" da canção, é um exemplo disso. Essa SLA apresenta ainda a noite como tempo da diversão. O local propício para o lazer e o prazer é a pista de dança "disco club" do "baile da pesada", caracterizada como lugar de realização de diversão "bárbara". A pista é reluzente e brilhante, como as alucinações causadas pelo $L S D$, de acordo com as descrições de Huxley e Leary.

"S.L.A. radical Dance Disco Club" é composta por um narrador onisciente (o "eu") que canta e conta para o leitor/ouvinte da canção a transformação efetuada, pelo som SLA, em uma "menina" (personagem do texto). Na narrativa, a "menina", sem nomeação, simboliza qualquer menina, melhor, qualquer pessoa. O valor veiculado na canção é o de que a transformação ocorrida com a personagem possa acontecer com qualquer pessoa, desde que ela, como a "menina" da canção, também se deixe embalar pelo suingue do som SLA do "baile da pesada".

Apesar de o narrador contar a história de um outro sujeito, ele se projeta e também nos projeta em alguns trechos de seu enunciado. Isso ocorre com a instauração da melodia na canção, em que a locução aparece e o efeito de sentido causado por ela é o de que o destinador-locutor "fala"/canta a narrativa da "menina" da canção ao destinatário-ouvinte. Por meio da primeira pessoa do plural (nós), o "eu" da canção se coloca identificado com o "outro" a quem dirige seu texto. Essa é uma estratégia de manipulação verbal que confirma o efeito de discurso direto instaurado pela melodia e assegura que o leitor aceite seu papel no contrato do /fazer/ narrativo da canção, identificado com a personagem. O narrador posiciona a "menina" no centro da pista de dança, local principal de transformação do estado de ânimo da "menina", que, antes, encontrava-se em sua casa ou nas ruas. Essa transformação de estados é "disparada" pelo som SLA (dispositivo entorpecente $L S D$ de FA) e pelo suingue (movimentação corpórea) de sua dança. A canção possui duas marcas temporais já no início do texto: "Hoje" e "noite". Essas marcas aproximam os sujeitos da canção, pois os transporta a um tempo comum: o tempo de "agora" do baile e da canção. O tempo narrado "hoje" é o tempo da "noite" (em contraposição ao tempo do dia), momento de prazer, lazer e diversão (em contraposição ao momento de dever, obrigação e trabalho mental próprio do "dia") e de "grande negócio", como afirma o "eu" da canção. Melhor, o tempo da festa, do suingue e do som SLA, tempo de "liberação geral".

$\mathrm{Na}$ canção, a transformação de estados ocorre pela tricotomia parar/não-parar/sem parar. Isso pode ser compreendido ao relacionarmos "parar" com a estaticidade e "sem parar"/“agir" com a mobilidade das palavras da menina em sua mente, depois, com os cinco sentidos e com o corpo da personagem que, ao dançar, na pista, "trabalha, trabalha, trabalha sem parar". Essa movimentação demonstra o estado de aflição imputado à "menina" pelo narrador, já que procura uma fuga para a aflição e a angústia que, segundo ele, a personagem sente com sua "vida dura". Assim, de acordo com a narração do "eu" da canção, podemos dizer que a "menina" possui um /dever-fazer/ e um /querer-fazer/ que, respectivamente, retrata seu estado de ânimo no início e no final da canção. No entanto, até ela ser entorpecida pelo som SLA, não consegue realizar nem sua obrigação nem seu desejo, ou seja, /nãopode(r) fazer/. A mudança ou a fuga da vida rotineira para o "baile da pesada" é o /fazer/ 
proposto na canção. Afinal, a vida da "menina" é caracterizada, no primeiro verso da canção, "como outra qualquer", comum, monótona e rotineira.

A adversativa ("mas") que inicia a terceira estrofe da canção indica a mudança a ser ocorrida com a "menina". Tanto quanto a negativa, o elemento adversativo pressupõe uma mudança oposta à situação anteriormente narrada. Assim, se a personagem, primeiro, encontra-se estática, a adversativa "mas" indica uma mudança, ou seja, a movimentação suingada e "divertida" da dança.

A mudança do artigo que acompanha a "noite", de indefinido ("uma") para definido ("a"), reorganiza o tempo da canção e colabora com a modificação dos estados de ânimo da "menina", que deixa de estar numa noite "como outra qualquer" e passa a viver "a noite", especial e diferente, aquela que "soluciona" sua estaticidade rotineira. O verbo decidir no presente do indicativo, no segundo verso da terceira estrofe, revela a primeira tomada de atitude (primeiro /fazer/) da "menina". Há, então, uma transformação de estado sofrida pela menina: de indecisa e angustiada para decidida ("decide sair e caminhar pelas ruas"). Essa decisão de se movimentar é, na verdade, uma decisão (seu /querer/) de ruptura com o estado inicial de estaticidade que a leva à etapa da performance narrativa, direcionada a um segundo estado, de mobilidade, caracterizado pelos verbos "sair" e "caminhar". O espaço, privado da casa, também muda, passa a ser público e coletivo, o das ruas, local de agitação e movimentação (marcado pelo "ir" e "vir"), retratado no plural.

Podemos afirmar que o som, personificado (SLA), caracteriza-se como sujeito do discurso da canção, bem como impõe a diversão à "menina" como dispositivo "solucionador" (de ruptura) com a estaticidade "enfadonha" na qual a personagem se encontra no início da canção. Sob esse prisma, o som que surge, quase que no centro da canção, assume o papel de sujeito enquanto que a "menina", aparentemente retratada como sujeito, ao aceitar o contrato proposto por esse sujeito-som, passa a ser seu objeto.

O refrão separa a canção em dois momentos, o estado inicial e o estado final da personagem narrada. Além disso, ele apresenta o som SLA como elemento responsável pela transformação de estados da e na "menina". Contudo, a sigla SLA, incluída no enunciado não parece um enigma. Ao contrário. A dispensa de explicação causa o "efeito de sentido" de que ou a sigla é autônoma e auto-explicativa ou é um código conhecido e dominado por todos: destinador-locutor, interlocutor e destinatário-ouvinte. Acompanhadas da sigla SLA, as expressões "radical dance disco club" e "radical dance club" caracterizam-na e a incluem no universo do soul-funk dos anos 70. Esses lexemas nos remetem a diversos mundos: às culturas norte-americana e carioca; ao universo do soul-funk e da música eletrônica (pelo vocabulário e pela melodia da canção); às décadas de 70 e 90 (pela expressão "disco club", que nos remete aos "embalos de sábado à noite" e também nos remete às boates high society das raves atuais); e ao mundo do lazer e da diversão (pela alusão a clubes, boates e discotecas).

O espaço do baile também é narrado como sujeito que, junto com o som SLA ( $L S D)$, seduz a "menina" a não apenas entrar no local, mas a passar a fazer parte desse novo mundo. O baile é o novo universo, caracterizado como um "ambiente requintado e cru". Essa caracterização contraditória reflete o "ambiente" das festas funk cariocas contemporâneas, uma vez que "requintado" significa sofisticado, "artificial", elegante, "fino" e, por sua vez, "cru" nos remete a "selvagem", "natural", "real". Esses dois qualitativos também nos remetem à mistura social existente no "baile da pesada", seja o das boates high society seja o das comunidades do Rio, onde o espaço é "requintado" - com móveis, luzes, bebidas, aparelhagem e efeitos sonoros computadorizados, pessoas de diversas classes e grupos sociais, com suas roupas, maquiagens, cabelos, sapatos e carros da moda "zona norte-zona sul" - mas a música, a dança e as relações entre as pessoas que lá se encontram são "cruas", 
uma vez que calcadas na sexualidade à flor da pele, no corpo, nos sentidos e no nivelamento e não na hierarquização econômica.

Podemos dividir a canção em três momentos: o primeiro, marcado pelo estado inicial de disforia em que se encontra a "menina", "lá" (em sua casa) e "então" (rotina cotidiana) - as duas primeiras estrofes; o segundo, em que a transformação entre o primeiro e o segundo estado ocorre com o som SLA - terceira, quarta e quinta estrofes; e o terceiro, marcado pela instauração da mudança de estado da personagem (estado final da "menina"), que passa a habitar o "aqui" e "agora" da canção - última estrofe.

O primeiro estado, disfórico, marcado na canção pela rotina da "vida dura" da "menina", "lá" ("lá está a menina", em sua "casa") e "então" (numa "noite como outra qualquer") é marcado pela estaticidade ("parada e pensando") e pelo trabalho da mente da personagem ("Sua mente trabalha, trabalha sem parar").

O segundo estado, eufórico, ocorre em oposição ao primeiro. A personagem passa a habitar o "aqui" do "baile": "Um ambiente requintado e cru", com "Um som vital, um ritmo quente" e "Uma pista multirreluzente" - e o "agora", tanto do baile quanto da canção - "a noite". A instauração desse estado, o estado final no qual se encontra a "menina" na penúltima estrofe da canção, ocorre com a interrupção do trabalho mental pela movimentação/trabalho de seu corpo e pelo aguçamento de seus sentidos (olhos, boca, mãos e coração), por meio da dança, sugerido pela iluminação ("multirreluzente") do "ambiente" da pista. O elemento que possibilita a mudança de estados da personagem é o som (adjetivado como "vital") que a toma/entorpece com seu embalo e se impõe como outro/novo ritmo ("quente", "radical") à "menina" no decorrer da canção.

Podemos dizer que o estado disfórico inicial da "menina" ocorre por ela se encontrar disjunta do universo SLA, mundo da diversão, defendido como uma outra lógica, invertida, do mundo, o prazer corpóreo, extraído da música e da dança; e conjunta ao universo da obrigação, repelido como rotineiro, enfadonho e chato pelo narrador. Já o estado final em que se encontra é eufórico porque oposto ao primeiro.

Contudo, a transformação de estados de ânimo sofrida pela personagem possui um significado mais profundo que apenas mostra a preferência da "menina" pelo mundo do lazer. Ao apresentar a distinção fórica entre obrigação e diversão, o narrador propõe não só a transformação de estado de ânimo de um sujeito-objeto para um sujeito-sujeito ("menina"), pois, por meio de um exemplo individual, encontramos uma proposta de transformação coletiva: a mudança da valorização do mundo por trabalhos diferentes. Afinal, o mundo disfórico, representado pelo estado de desânimo inicial da menina é o mundo do trabalho da mente e das palavras, o mundo do pensamento, enquanto que o mundo eufórico, representado pela descoberta de uma nova ordem, é o mundo do trabalho corpóreo, do balanço/suingue (dança) do "baile da pesada", embalado pelo som (música) SLA. Nesse sentido, o trabalho do pensamento e das palavras é simbolizado como angustiante e depressivo, enquanto que o universo da música e da dança funk, ao representar a "solução", a "cura" ou o alívio para o desânimo e desespero da "menina", simboliza o universo da festa, do lazer e da diversão que, ao interromper a mente e acionar o trabalho do corpo, traz o prazer e a "liberdade" ao ato de dançar como proposta resistente de ruptura com a valorização racional vigente, mas também se caracteriza pela entorpecência da "menina", que se entrega à música SLA.

Podemos visualizar essa transformação de estados da "menina" ao compararmos a primeira e segunda estrofes com a sexta: 
Primeira e segunda estrofes

\author{
"Hoje é uma noite como outra qualquer \\ E na sua casa vemos uma menina \\ Uma menina muito interessante \\ E mesmo que não pareça, sua vida é dura \\ Hoje é uma noite qualquer \\ E lá está a menina, parada e pensando \\ sentindo as palavras indo e voltando \\ sua mente trabalha, trabalha sem parar"
}

Estado inicial disfórico, marcado pelo trabalho da mente e pela estaticidade do corpo da menina.

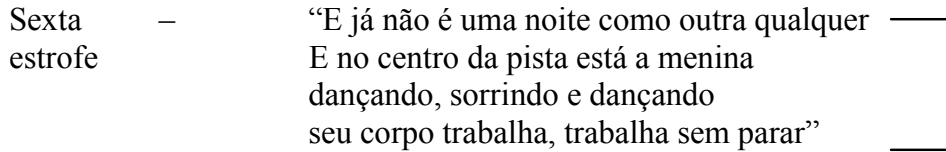

Estado final eufórico, marcado pela interrupção do trabalho da mente e pela instauração do movimento corporal da menina.

A negação do estado anterior no qual se encontrava a "menina" narrada, também marcada pelo advérbio "já", na última estrofe da canção, indica a mudança ocorrida do primeiro para o segundo estado vivido pela personagem e pela manipulação sofrida por ela ${ }^{8}$, pois denota duas situações vividas pela "menina": uma, a primeira, disfórica, monótona, desanimada e depressiva, a da ordem do mundo vigente, do trabalho-obrigação e da rotina; outra, a segunda, eufórica, agitada, animada, a da ordem do mundo do lazer, do trabalho do corpo (suingue), da diversão, dos sentidos, do prazer, enfim, do clube SLA. A transformação ocorrida na canção é narrada como eufórica porque a ordem do mundo do lazer e da diversão aparece regida pela lógica da música e da dança SLA, responsáveis por uma aparente libertação do estado depressivo em que se encontrava a "menina". Esse segundo estado vivido pela personagem, apesar de ser narrado como eufórico e resistente, caracteriza-se como tão entorpecente quanto o primeiro, pois a "menina" continua no mesmo estado em que se encontrava no início do texto, agora, regido por um outra lógica, ainda que a ordem do mundo continue a mesma. A única diferença é a ilusão vivida pela "menina" de que sua depressão se transformou em alegria e prazer quando, no fundo, a música e a dança apenas a tiraram do contato com sua "dor", por meio da fuga temporária ao mundo SLA, caracterizado como "funky club", conforme "Disco Club 2 (Melô do radical)".

À medida que o corpo da menina inicia sua movimentação por meio da dança e de seus sentidos aguçados, ocorre o processo inverso com sua mente que, antes, em plena "ação", "pára": "seu pensamento é interrompido". Assim, a razão é interrompida e, com ela, a produção e a obrigação. O responsável pela interrupção da ação do pensamento da personagem é o som, ou seja, a música, o $L S D$ "hipnótico" de FA. Essa música resistente (elemento que tira a menina da monotonia de sua rotina e do "transe" de seus pensamentos) e entorpecente (dispositivo que coloca a menina num outro "transe", o do corpo e dos sentidos, e a leva até a pista de dança, por "hipnose") surge no centro do /fazer/ manipulador do discurso verbal da canção, personificada, por ser caracterizada também pelo andar da "menina". Sua função de interrupção tem por objetivo chamar a atenção do corpo da personagem e seduzi-lo a levá-lo até o local de onde vem: a pista de dança. Para atingir sua finalidade, o som "corta", interrompe o trabalho executado pela mente da "menina". No entanto, a mesma SLA lhe atribui um outro trabalho, o do corpo, por meio da dança. Sob esse prisma, não há mudança, pois os dois estados narrados correspondem a dois mundos calcados

\footnotetext{
${ }^{8}$ A manipulação por sedução é a perfórmance das palavras de seus pensamentos que a fazem se movimentar sair e caminhar; do som, que a seduz; e do espaço da pista de dança, que lhe apresenta um outro mundo, diferente do habitual
} 
em dois tipos de trabalho. A diferença se refere à valorização atribuída aos dois tipos de trabalhos narrados: a disforia ao trabalho-obrigação da mente versus a euforia ao trabalhodiversão do corpo. Nesse sentido, a primeira e a segunda estrofe versus a sexta podem ser consideradas espelhos (com imagens invertidas) dos dois estados de ânimo narrados, uma vez que se caracterizam como contrárias, sendo uma, a negação da outra.

A estratégia discursiva da canção pode levar o "outro" (ouvinte/leitor) a se identificar com a "menina", a sentir-se "livre" para "escolher" o que acredita ser melhor para si. Essa identificação colabora para a realização do contrato de manipulação proposto pelo "eu" (narrador) da canção, desde o início: de que o "outro" (leitor) deve /querer fazer/ algo (movimentar-se) para mudar seu estado de ânimo, de depressivo para eufórico. Assim, a busca proposta pelo "eu" leva o "outro", por meio da "menina", à pista de dança SLA, que aparece como "solução" para os problemas que parece viver, tanto a "menina" narrada quanto o destinatário-ouvinte, projetado nela. A aparente liberdade de escolha, no entanto, não se sustenta, uma vez que o "poder de observação" da "menina" se desfaz diante do /poder/ do som SLA $(L S D)$ - ao mesmo tempo "dispositivo de controle" e "expansão da mente" - que, sem oferecer opção, "hipnotiza" a menina que, sem se dar conta, entrega-se ao "clube SLA" e começa a "balançar", embalada pelo som e pelas luzes daquele espaço "brilhante", agitado, diferente, "encantado" e "multirreluzente" da pista de dança, onde se encontra.

Assim, a "menina", envolvida e entorpecida, inicia sua ação (que pensa ser sua manifestação de resistência - recusa ao mundo do trabalho mental "robótico", rotineiro) e aceita a manipulação proposta como aparente liberdade, ainda que "alucinada" pela linguagem musical. Seu corpo passa a se movimentar (olhos, boca e mãos) até que o estado de "anestesia" e, ao mesmo tempo, "alucinação" causado pelo som SLA chega e domina os sentidos e sentimentos (o coração) da personagem, já metamorfoseada do primeiro estado de ânimo em que se encontrava no início do texto, o "lá" e o "então" do enunciado, para esse segundo estado (euforia escapista), no qual se encontra "agora", em fusão com o "aqui" e o "agora" do "clube SLA", do "baile da pesada" e da canção.

\section{Conclusão}

Nas canções de FA, como ocorre em "SLA radical dance disco club", o baile surge como "aliviador" de tensões (como afirma o sujeito da canção "Baile da Pesada": "a condição aliviar"), ou melhor, "solução" dos problemas cotidianos vividos (conforme os versos de "Disco Club 2 (Melô do radical)" recuperada em "Bloco Rap Rio", em que o destinadorlocutor afirma para o interlocutor da canção e, por meio dele, para o destinatário-ouvinte que "a solução pros seus problemas acabou de chegar / É radical, party"). Todavia, a "party" de FA possui traços tanto do funk dos anos 70 quanto dos anos 90 e 2000, pois mistura os ritmos musicais em suas canções e ainda cita, textualmente, nomes de personagens emblemáticos do funk desses dois momentos e os coloca lado a lado na mesma canção, melhor, no mesmo "baile da pesada", o seu "clube SLA", bem como sintetiza e sampleia trechos ou canções inteiras de ambas as épocas em suas SLAs. Além disso, também nomeia os sujeitos citados como "galera sangue bom" e "galera" do baile e do som "radical". O som funk dançante e, muitas vezes, "quebrado" pela levada do samba, está comprometido com os "mandamentos black", "paz e amor", originários do movimento "Black Rio" e estendido para um dos sub-gêneros do new funk atual, o "samba funk". Para os sujeitos das canções de FA, esse é o "genuíno" processo de "funkinização" pelo qual "deve" passar o país, e não o "proibidão" ou o funk mellody de "popuzudas" e "tigrões" difundido pela mídia e esvaziado 
de sentido por nada ter a ver com a história cultural e social pela qual passou o funk carioca desde meados dos anos 70. Nesse sentido, a obra de FA possui, também, o papel de intermédio ou ligação entre esses dois funks e seus respectivos momentos históricos. A "filigrana" que liga esses dois funks é o suingue dançante, talvez por isso a festa (o "baile") seja central em sua obra e apareça como "solução". O baile é a "solução" para a monotonia cotidiana porque institui, no lugar da seriedade do trabalho e da razão ordinária, colocada de maneira disfórica nas canções, a alegria e o riso carnavalesco da festa como ordem imperativa eufórica.

O suingue, foco de nossa análise, aparece de forma central na festa, em torno da qual se constrói a metalinguagem. Por isso, depreendemos o significado do baile, a fim de, por meio de sua estruturação e dinâmica, entender a busca por um pertencimento nesses locais.

Em "SLA radical dance disco club", não existe uma proposta de re-estruturação social para que o trabalho, visto como obrigação, possa vir-a-ser diversão e proporcionar prazer, pois a exploração do trabalho sequer é questionada. Ao contrário. A transformação proposta parece ser simples e fácil, basta o sujeito se "fazer parte de" (pertencer a) o clube SLA. Mas, a única diferença entre o mundo do trabalho-obrigação e o universo do trabalhodiversão corpórea, caracterizada pela música SLA e pelo suingue funk, é a inclusão do prazer e do lazer como valor vigente, porém sua inclusão é realizada, também, por meio de um tipo de trabalho. Assim, podemos refletir se a foria estabelecida na canção se refere a uma mudança/transformação de estados sociais ou se é apenas uma maneira de inclusão e incorporação da lógica e do mundo do funk como possibilidade de produção capital, tanto quanto qualquer outro tipo de trabalho "duro".

Sob outro aspecto, podemos pensar que a ausência de proposta significativa de mudança estrutural talvez seja a proposta resistente da canção - apenas "dizer não" ao universo do trabalho-obrigatório. Todavia, ao utilizar os mesmos mecanismos do mundo vigente, essa proposta se instala como forma de entorpecência, pois seja no mundo do trabalho mental seja no universo do trabalho corpóreo, o sujeito trabalhador, no caso de "SLA radical dance disco club", a "menina" possui o mesmo papel: marionete manipulável pelos fios quase invisíveis do discurso hegemônico, seja ele o do mundo rotineiro seja ele o do "clube SLA".

Além disso, a incorporação do universo SLA como trabalho, transformado em produto rentável, como retratado na canção analisada, de certa forma, "reflete e refrata" o processo de "funkinização" pelo qual passa o país na contemporaneidade, uma vez que o funk tem sido valorizado pelos meios de comunicação de massa como "fenômeno cultural carioca e brasileiro" e transformado em produto de consumo pela indústria fonográfica, que tem ganhado muito com a bombástica vendagem desse estilo musical nos últimos cinco anos batendo índices de vendagem de todos os outros gêneros musicais. Assim, o que era "som de preto, de favelado", desvalorizado e invisível adquire visibilidade como objeto que necessita ser produzido e consumido cada vez mais, uma vez que usado como o "filão" da vez, transformado em "moda", depois da conquista do mercado local (carioca), nacional e internacional, feita pelo marketing televisivo e radiofônico de promoção desse ritmo.

Ao acusar o mundo do trabalho-obrigação e caracterizá-lo como disfórico, o narrador pretende conquistar adeptos ao mundo SLA para fortalecê-lo e enfraquecer, conseqüentemente, o mundo racional vigente. Ao conseguir manipular os sujeitos da canção e tê-los como defensores do universo do trabalho-corpóreo, a música SLA pode sair de seu espaço periférico de invisibilidade, exclusão e reclusão, e tomar o "centro da pista", ou seja, ela adquire competência para entrar em conjunção com o objeto desejado, o poder. Assim, ao 
"trocar de lugar" com o universo do trabalho-obrigação, o mundo-SLA, antes contracultura, transforma-se em cultura hegemônica. Essa modificação, ao ser realizada, encerra o propósito de manipulação do narrador e a própria canção. Talvez, por isso o desfecho da canção (não apenas dessa, mas da maioria das canções de FA) ocorra com a realização da mudança de estados de ânimo da "menina" que, no centro da pista de dança, encontra-se "feliz".

Em suma, em "S.L.A. radical dance disco club", a noite aparece como tempo de "um grande negócio" para os sujeitos pertencentes ao "clube SLA", sujeitos compostos pelo suingue próprio do funk, localizados no espaço da pista "dance disco club" e retratados como integrantes de um "clube radical", composto por canções e sujeitos "sangue bom". Afinal, a noite é o tempo do lazer e do prazer, ou melhor, momento da realização do trabalho corpóreo, o trabalho-diversão. Nesse sentido é que, como ocorre em "O céu pode esperar" o "lema" do suingue "carpe diem" aparece como "solucionador" e "aliviador", uma vez que "os filhos, os amigos, o amor é o que interessa". Além disso, a valorização do processo de "funkinização" SLA como estado de ânimo eufórico é retratado nas canções de FA pela afirmação de que "não basta só viver, eu quero a felicidade" ("O céu pode esperar") e, para os sujeitos das canções de FA, a felicidade se relaciona com o trabalho prazeroso e não apenas com o trabalho-obrigatório, ainda que a diversão apareça como um outro tipo de trabalho.

\section{Referências Bibliográficas}

ABREU, F. SLA radical dance disco club. Rio de Janeiro: EMI-Odeon, 1990.

Raio X. Rio de Janeiro: EMI-Odeon, 1997.

BARROS, D.L.P. de. Teoria semiótica do texto. São Paulo: Ática, 1990.

BERTRAND, D. Caminhos da semiótica literária. São Paulo: EDUSC, 2003.

ESSINGER, S. Batidão: uma história do funk. Rio de Janeiro: Record, 2006.

FARIAS, I.R. Sujeito e discurso na canção RAP: o (en-)canto das palavras. Dissertação de mestrado. Araraquara: UNESP/CAr., 1997 (mimeo).

FRENETTE, M. “O marginal integrado". Bravo. http://www.bravonline.com.br, consultado no dia 10/07/2006, às $00 \mathrm{~h} 15 \mathrm{~min}$.

HERSCHMANN, M. O funk e o hip hop invadem a cena. Rio de Janeiro: UFRJ, 2006.

HUXLEY, A. As portas da percepção. São Paulo: Globo, 2002.

TATIT, L. Elementos semióticos para uma tipologia da canção popular brasileira. São Paulo: FFLCH - USP, 1986. Tese de Doutorado. (Mimeo)

O cancionista: composição de canções no Brasil. São Paulo: Edusp, 1996.

. Musicando a semiótica. São Paulo: Annablume/FAPESP, 1998.

VIANNA, H. O mundo funk carioca. Rio de Janeiro: Jorge Zahar, 1988.

Wikipédia, a enciclopédia livre .http://www.hostgold.com.br/Funk\#História, consultada em 08/06/2006, $18 \mathrm{~h}$. 
CASA, Vol.4, n.2, dezembro de 2006

\section{ANEXO}

\section{S.L.A. Radical dance disco club}

Hoje é uma noite como outra qualquer

E na sua casa vemos uma menina

Uma menina muito interessante

E mesmo que não pareça, sua vida é dura

Hoje é uma noite qualquer

E lá está a menina, parada e pensando

Sentindo as palavras, indo e voltando

Sua mente trabalha, trabalha sem parar

Mas ela sabe que a noite é um grande negócio

Então decide sair e caminhar pelas ruas

Seu pensamento é interrompido por um som

Vindo de um lugar não muito distante

Sla radical dance disco club

Sla radical dance club

Foi só ela entrar e se deparar

Com um ambiente requintado e cru

Um som vital, um ritmo quente

Uma grande pista multirreluzente

Ela gosta de excitar seus sentidos

De ampliar seu poder de observação

Seus olhos tentam ver tudo, e assim

Sua boca, sua mão e assim seu coração

E já não é uma noite como outra qualquer

E no centro da pista está a menina

Dançando, sorrindo e dançando

Seu corpo trabalha, trabalha sem parar

Sla radical dance disco club

Sla radical dance club 